Азиатско-Тихоокеанский регион: экономика, политика, право. 2021. Т. 24, № 4. С. 89-98. Pacific Rim: Economics, Politics, Law. 2021. V. 24, No 4. P. 89-98.

\title{
ПОЛИТИКА
}

Научная статья

УДК 32(519.3)

https://doi.org/10.24866/1813-3274/2021-4/89-98

\section{КОРЕЙСКАЯ НАРОДНО-ДЕМОКРАТИЧЕСКАЯ РЕСПУБЛИКА: БОРЬБА ЗА ВЫЖИВАНИЕ И СОХРАНЕНИЕ СУВЕРЕНИТЕТА}

\section{Забровская Лариса Вячеславовна}

Институт истории, археологии и этнографии Дальневосточного отделения

Российской академии наук, 690091, Россия, Владивосток,

ул. Пушкинская, 89, larisa_zabrovska@mail.ru

Аннотащия. Изучены действия властей Корейской Народно-Демократической Республики (КНДР) по предотвращению проникновения коронавируса на территорию страны. Прослежена последовательность мер, принятых властями. Определён характер кадровых перестановок, выявлены причины самокритики властей. Показаны новые тенденции в методах северокорейского руководства. Раскрыта роль Ким Ё Чен в отношениях КНДР с Республикой Корея (РК). На основе материалов VIII съезда Трудовой Партии Кореи (ТПК) исследованы задачи партии и страны на следующую пятилетку. Определены приоритетные направления экономического развития КНДР. Сделан вывод о возможном закрытии страны на продолжительное время в целях защиты населения от эпидемии и враждебной идеологии извне.

Ключевые слова: КНДР, пандемия COVID-19, Ким Чен Ын, Ким Ё Чен, VIII съезд ТПК, Мун Чжэ Ин, Си Цзиньпин, Д. Трамп, Дж. Байден, Китай, Корейский полуостров, Японское море, Пхеньян, Кэсон, Вонсан, Сеул, Тэгу, Республика Корея, антиковидные меры, гуманитарная помощь.

Для иитирования: Забровская Л. В. Корейская Народно-Демократическая Республика: борьба за выживание и сохранение суверенитета // Азиатско-Тихоокеанский реги-он: экономика, политика, право. 2021. Т. 24, № 4. С. 89-98. https:// doi.org/10.24866/1813-3274/2021-4/89-98. 


\section{POLITICS}

Original article

\section{DEMOCRATIC PEOPLE'S REPUBLIC OF KOREA: THE STRUGGLE FOR SURVIVAL AND PRESERVATION OF SOVEREIGNTY}

\section{Larisa V. Zabrovskaya}

Institute of History, Archeology and Ethnography,

Far Eastern Branch of the Russian Academy of Sciences, 89 Pushkinskaya St.,

Vladivostok, Russia, larisa_zabrovska@mail.ru

Abstract. The actions taken by the Democratic People's Republic of Korea (DPRK) authorities for preventing the spread of coronavirus in the country were studied. The sequence of measures taken by the authorities was reviewed. The nature of personnel changes has been determined; the reasons for the authorities' self-criticism were identified. New trends were revealed in the control methods by the North Korean leadership. The role of Kim Yo Jong was determined in the relations between the DPRK and the Republic of Korea (ROK). The tasks of the Party and the country were investigated based on the materials of the 8th Congress of the Workers' Party of Korea (WPK).

Key words: DPRK, COVID-19 pandemic, Kim Jong Un, Kim Yo Jong, $8^{\text {th }}$ Congress of the WPK, Moon Zhe Ying, Xi Jinping, D. Trump, J. Biden, China, Korean Peninsula, Sea of Japan, Pyongyang, Kaesong, Wonsan, Seoul, Daegu, Republic of Korea, anti-COVID measures, humanitarian aid.

For citing: Zabrovskaya L. V. Democratic People's Republic of Korea: the struggle for survival and preservation of sovereignty // Pacific RIM: Economics, Politics, Law. 2021. V. 24, No. 4. P. 89-98. https://doi.org/10.24866/1813-3274/2021-4/89-98.

В 2020-2021 гг. КНДР переживала сложный период своей истории. Стихийные бедствия, неурожай, эпидемия COVID-19 наложились на непрекращающиеся международные санкции, подрывающие и без того слабую северокорейскую экономику. Прежде чем делать выводы и прогнозы о путях выхода КНДР из сложного периода её истории, связанного с пандемией коронавируса, необходимо проанализировать важные события 2020-2021 гг., которые прошли под знаком необходимости поддержания здоровья населения страны и сохранения государственной власти за семьёй Кимов. 


\section{Борьба властей с пандемией}

После первых сообщений из южного Китая о начале массового заболевания китайского населения власти КНДР начали принимать соответствующие меры по защите собственных граждан. В 2020 г. Ким Чен Ын пропустил своё новогоднее обращение к народу, так как не было ясно, насколько пандемия затронет КНДР. Поэтому не было смысла планировать ход дальнейшего развития экономики и определять другие задачи. По мере выхода пандемии из-под контроля в Китае в КНДР начали ужесточать антиковидные меры, прежде всего, путём закрытия 13 февраля 1200-километровой китайско-северокорейской границы. Учитывая ограниченные возможности северокорейского здравоохранения, власти КНДР ввели 30-дневный карантин для всех приезжающих из-за границы. Авиаперелёты и железнодорожное сообщение с Китаем были приостановлены, что затруднило доставку гуманитарной помощи в КНДР [1, с. 54-55].

Внутри страны сотни небольших мобильных медицинских бригад расследовали все случаи заболеваний. Контрольно-пропускные пункты отслеживали симптомы простудных заболеваний у населения. Трансляции из громкоговорителей доводили до населения сведения об опасности новой болезни и то, как от неё защититься. Высокопоставленные чиновники во главе с премьером Ким Чжэ Рёном объехали всю страну, выясняя степень нехватки продовольствия, медикаментов и электроэнергии. По мере распространения пандемии в соседних странах северокорейские власти постоянно заявляли об отсутствии заболевших среди граждан КНДР. Заболевшие иностранцы изолировались и, по мере возможности, отправлялись на родину. При таких строгих мерах были предотвращены крупномасштабные, в сравнении с Республикой Корея (РК), вспышки, а возможно - и массовое заболевание COVID-19 северокорейского населения.

В течение весны и лета Ким Чен Ын продолжил уделять внимание проблемам здравоохранения. Он проводил инспекционные визиты в больницы Пхеньяна и регионов. Особое беспокойство властей вызвал инцидент в Кэсоне с южнокорейским перебежчиком, который был заражен COVID-19. Город был заблокирован на следующие три недели. Власти повысили бдительность по всей стране [1, с. 57].

Строгость и бескомпромиссность закрытия границы была продемонстрирована 21 сентября, когда северокорейский морской патруль обнаружил в Японском море нарушителя границы, расстрелял и сжёг его лодку, а самого нарушителя утопил. Однако затем оказалось, что это был сотрудник южнокорейского рыбного ведомства, который просто заблудился. В связи с этим Ким Чен Ын послал Мун Чжэ Ину примирительное письмо с извинениями, но этот инцидент оставил неприятный осадок у южнокорейской общественности. Тем не менее число перебежчиков с той и другой стороны резко сократилось. 
По мере расширения территории Китая, охваченной коронавирусом, правительство КНДР отправило туда гуманитарную помощь в виде медицинских масок. В письме к Си Цзиньпину Ким Чен Ын заметил, что небольшой объём помощи хотя и «символичен, но преследует цель хоть немного помочь» дружественной стране [5]. Этот шаг был предпринят в надежде на то, что когда КНДР будет нуждаться в аналогичной помощи, то Китай также окажет содействие.

Власти КНДР серьёзно забеспокоились в конце февраля 2020 г., когда южнокорейский город Тэгу стал очагом распространения COVID-19. Ким Чен Ын созвал Политбюро ЦК ТПК, на котором обсуждались вопросы защиты населения от пандемии и возможного обострения обстановки на Корейском полуострове. Затем он приступил к руководству военными учениями, начав с отработки бомбометания по острову в гавани порта Вонсан, а затем приступил к руководству испытаниями ракет малого радиуса действия [6]. В то же время его сестра Ким Ё Чен раскритиковала южнокорейских военных за серию испытаний новой баллистической ракеты «Хюнму-4» с дальностью полета 800 км.

Кроме руководства военными маневрами Ким Чен Ын стремился продемонстрировать, что для него «жизнь и здоровье людей являются самым важным государственным делом» [7]. Он объявил о начале строительства в Пхеньяне современного медицинского учреждения общего профиля.

В условиях расширения в соседних странах территории, охваченной пандемией коронавируса, в апреле было созвано Верховное народное собрание КНДР, на котором работа Кабинета министров была подвергнута критике за «серьёзные ошибки». Высшим государственным чиновникам предъявили требование соблюдать принцип «всё подчинить здоровью и безопасности народа» [9]. Собрание одобрило увеличение госрасходов на здравоохранение на 7\% и оставило без изменений оборонный бюджет. Были сделаны кадровые перестановки, касающиеся замены министра иностранных дел, обороны и безопасности. После этого Ким Чен Ын ограничил своё появление на публике скорее всего из-за распространения пандемии.

Тем временем его сестра Ким Ё Чен проявила внешнеполитическую активность и в начале июня выступила с очередным осуждением правящих кругов РК, на этот раз за разрешение запуска вдоль демилитаризованной зоны воздушных шаров с антисеверокорейскими листовками. Кроме того, гнев Пхеньяна вызвали итоги выборов в южнокорейском парламенте (Национальное собрание), куда были выбраны в качестве депутатов перебежчики из КНДР. По этому случаю в КНДР прошли массовые митинги, где перебежчики были объявлены «человеческими подонками». Кроме того, Ким Ё Чен приказала снести здание межкорейского офиса связи в Кэсоне, что почти через 20 лет после первого межкорейского саммита разрушило канал связи с Сеулом. 
В то же время, несмотря на события, происходящие в РК и задевающие чувства и интересы КНДР, Ким Чен Ын хранил молчание, позволив своей сестре дать оценку поступкам Сеула. В результате в декабре 2020 г. Нацсобрание (парламент) РК приняло поправку к Закону о межкорейских отношениях, запрещающую методы психологической войны против КНДР, что также включало и запрет на разброс антисеверокорейских листовок. Стоит задуматься, так ли плохо избрание бывших северокорейских перебежчиков в парламент РК, как это предположили в КНДР. Возможно, в будущем такой метод взаимодействия сможет привести к конвергенции двух частей Кореи.

Кроме того, южнокорейское правительство направило КНДР гуманитарную помощь через международные фонды. В результате южнокорейская помощь в виде 50 тыс. т риса поступила в World Food Programme, в United Nations Children's Fund (UNICEF) - 8 млн долл., а через World Health Organization было направлено 5 млн долл. Однако КНДР отвергла такого рода поддержку, поскольку предпочитает получать прямые южнокорейские инвестиции в северокорейскую экономику [8, p. 82].

3 июля прошло заседание Политбюро ЦК ТПК, где Ким Чен Ын снова выразил недовольство антипандемической работой и предупредил о возможности «невообразимого кризиса», если превентивные меры потерпят неудачу [10]. Затем Ким Ё Чен вновь обрушилась с критикой на Мун Чжэ Ина и США. При этом подчёркивалось, что президент Д. Трамп по-дружески относится к КНДР, а в целом США занимают враждебную позицию. Она заявила, что США должны сесть за стол переговоров с новыми предложениями и устранить свою «враждебную политику» в отношении КНДР [11].

В течение всего лета 2020 г. Ким Чен Ын продолжал уделять пристальное внимание внутренним проблемам, прежде всего здравоохранению, и посетил ряд больниц в Пхеньяне. Затем в начале августа на Корейский полуостров обрушились обильные дожди и тайфуны. Особенно пострадали северо-восточные провинции - Северная и Южная Хамгён, которые посетил Ким Чен Ын и дал указания местным чиновникам. Затем на Политбюро была обсуждена проблема «двух кризисов» - пандемии и наводнений. Премьер Ким Чжэ Рён был заменен другим технократом - Ким Ток Хуном (Kim Tok Hun). На Пленуме ЦК ТПК Ким Чен Ын объявил о своём намерении провести очередной съезд партии в январе 2021 г. Он запланировал проводить съезды каждые 5 лет, как в Китае, и связывать их решения с долгосрочным экономическим планированием. На этом пленуме было признано, что задачи развития страны, запланированные VII съездом ТПК в 2016 г., не были выполнены, поскольку экономический рост был «серьёзно задержан, и уровень жизни населения не повысился» [12]. Новый экономический план должен быть утверждён следующим съездом ТПК. 
Тем временем тайфуны продолжали бушевать на всей территории КНДР. Ким Чен Ын вновь совершил поездку в пров. Южная Хамгён, где обратился с открытым письмом ко всем членам партии с просьбой активно участвовать в восстановительных работах, особенно в шахтерских городах региона Комдок, где находятся шахты по добыче редкоземельных металлов, широко используемых в электронной промышленности. Руда из этих шахт идет на экспорт, принося КНДР так необходимую валюту. Поэтому собравшееся в шестой раз в 2020 г. Политбюро ЦК ТПК предостерегло от «самоуспокоенности и безответственности» в экономической сфере и определило новые инструкции по ужесточению антипандемических мер, в частности, усилив контроль за границей с Китаем и РК.

В связи с подготовкой к съезду и сложным экономическим положением в стране была объявлена «80-дневная битва», в ходе которой все северокорейские трудящиеся обязывались интенсивно трудиться и, работая сверхурочно, перевыполнять планы по производству товаров. Южнокорейские обозреватели подсчитали, что это явилось 13-й с 1948 г. «трудовой вахтой», когда власти КНДР заставляли своих граждан трудиться сверхурочно. Они также заключали, что в период правления Ким Чен Ына такие «вахты» участились, объясняя это тем, что молодому вождю важно «поднять уровень экономики страны и укрепить свою власть. Поэтому он нуждается в таких «трудовых битвах» [14, p. 5].

\section{Международные контакты}

Во второй половине 2020 г. Ким Чен Ын продолжил уделять внимание внутренним делам, но всё же находил время для переписки с лидерами соседних стран. Так, в сентябре он обменялся теплыми посланиями с президентом РК Мун Чжэ Ином, который также был озабочен распространением коронавируса в своей стране. Затем в октябре Ким Чен Ын отправил лидеру КНР Си Цзиньпину поздравительное письмо по случаю национального праздника, а также выразил сочувствие семье Д. Трампа после обнаружения у них положительного результата на COVID-19. Пхеньян никак не прореагировал на заявление кандидата в президенты Дж. Байдена, что Ким Чен Ын является «головорезом», и никак не отозвался на победу Дж. Байдена на выборах. Как видно, путём игнорирования нежелательных фактов и поддержания контактов с зарубежными лидерами Ким Чен Ын «держит дверь приоткрытой» для дальнейшего диалога.

В свою очередь Китай, являясь важным союзником КНДР, занял «нейтрально-пассивную позицию по корейской проблематике» и постарался дистанцироваться от обострившихся в июне 2020 г. межкорейских отношений. Китайское руководство ограничилось призывом проявить «сдержанность и разрешать разногласия мирными методами» [2, с. 73].

9 октября на военном параде по случаю очередной годовщины образования КНДР Ким Чен Ын выразил сожаление о том, что не смог «защитить здоровье 
населения», которое «оказало мне доверие» [13]. Он обещал поддерживать здоровье народа, так как это означает «само существование нашей партии, государства и всего на этой земле» [13].

В ноябре и декабре Ким Чен Ын присутствовал на траурных мероприятиях в мавзолее своего отца и на очередном заседании Политбюро, где указывалось на необходимость усиления «анти-пандемической работы», отмечалось, что ведётся тестирование населения и выявлено 6173 случая с подозрением на коронавирус, 8 из которых были иностранцы, и их отправили на родину $[15$, p. 6].

Таким образом, если 2019 г. был годом стратегической корректировки, то 2020 г. стал годом выживания страны и населения. Ким Чен Ын не стеснялся критиковать чиновников и сам раскаивался в своей беспомощности по защите населения от коронавируса. Ожидается, что 2021 г. станет годом восстановления и учётом ошибок прошлого.

\section{Решения и планы VIII съезда ТПК}

5-12 января 2021 г. в Пхеньяне прошел VIII съезд ТПК. Съезд окончательно закрепил власть Ким Чен Ына в партии и стране. Ким Чен Ын является главой государства, главнокомандующим вооружёнными силами и главой ТПК, сменив название этой должности с председателя на генерального секретаря ЦК ТПК. Таким образом, руководство ТПК отказалось от практики сохранять должности за умершими лидерами.

Текст доклада Ким Чен Ына, который зачитывался в общей сложности 9 часов в течение трёх дней, и другие материалы не были опубликованы, но стали доступны в кратком пересказе. Примечательно, что в отчётном докладе акцент сделан не на успехах, а на анализе ошибок и недостатков. Был значительно изменён состав участников в сравнении с предыдущим съездом. Доля представителей военных кругов составляла на VII съезде ТПК 19\%, а на следующем - всего лишь 9\%. Знаменательно, что 30\% всех участников VIII съезда ТПК - это представители первичных парторганизаций, что говорит о большом внимании Ким Чен Ына к партийному строительству и опеке над первичными звеньями ТПК. Идеологические лозунги не поменялись и свелись к призыву «опоры на собственные силы» (чарёк кэнсэн) [3, с. 171].

Основное внимание в материалах съезда уделено решению экономических задач: развитию металлургии, машиностроения, химической промышленности на основе газификации, а также механизации сельского хозяйства. В ходе заседаний Ким Чен Ын признал, что поставленные на VII съезде ТПК экономические задачи не были выполнены. Причинами послужили усиление антисеверокорейских санкций, стихийные бедствия, а также эпидемия COVID-19.

В новом пятилетнем плане (2021-2025) намечалось ликвидировать отставание в промышленности и сельском хозяйстве, продолжить развитие соб- 
ственной энергетики. В новой пятилетке приоритетными направлениями явились развитие металлургии и химической промышленности, развитие мобильной связи, импортозамещение на основе утилизации отходов, что позволит сократить импорт дорогостоящих исходных материалов. Иными словами, указывалось на необходимость перейти на самообеспечение стратегическими материалами и продукцией сельского хозяйства.

Продолжилась тенденция снижения объёмов внешней торговли, которая наблюдалась с 2019 г. Ранее на долю торговли с Китаем, главным внешнеторговым партнёром, приходилось 95,4\% (4-5 млрд долл.) от всего внешнеторгового оборота КНДР, но в 2020 г. этот показатель значительно снизился и достиг 0,5 млдр долл. Изменилась и структура импорта за счёт увеличения закупки продовольственных товаров, что может свидетельствовать о продуктовом кризисе в КНДР.

К проведению политики опоры на собственные силы КНДР подталкивает ожидание ухудшения международной обстановки и продолжение мирового кризиса здравоохранения. Поэтому на съезде подчёркивалась важная роль ракетно-ядерной программы КНДР как силы сдерживания внешнего давления [3, с. 173].

В целом VIII съезд ТПК продемонстрировал готовность решать реальные проблемы, адекватно признавать свои ошибки и промахи, преодолевать санкции, стихийные бедствия и пандемию коронавируса. Очередной съезд ТПК ещё раз подтвердил приверженность социалистическому выбору, страна продолжает руководствоваться идеологией кимирсенизма, систематизирующей идеи чучхе [3, с. 174].

В перспективе можно ожидать продолжение закрытия страны не только от внешнего идеологического влияния, но и от вирусных инфекций, что затруднит доставку гуманитарной помощи, медикаментов и в итоге приведет к снижению уровня жизни населения, но, возможно, сохранит государственный строй КНДР. В этом заключается смысл лозунга «служить народу как небу», который стал ведущим в период борьбы с коронавирусом. В частности, Ким Чен Ын заявил: «Наш народ в длительной, жёстокой обстановке, которую история до сих пор не знала, усвоил метод жить нашими силами, усвоил метод одолеть врага и трудности, и метод защитить своё достоинство и право. Собственным, хоть и затягивая пояс, самообогащением и процветанием, собственными силами необходимо защитить достоинство страны и победить империалистов» [4]. По всей видимости, Ким Чен Ын решил в новых исторических реалиях реанимировать ранее успешно опробованный его дедом экономический приём «опоры на собственные силы».

$$
* * *
$$

В целом можно констатировать, что власти КНДР, активизировав санитарноэпидемиологические действия, успешно локализуют распространение эпидемии 
COVID-19 и не допускают массовых вспышек этого заболевания. В условиях внешнего военно-политического давления и затяжного характера экономических санкций власти КНДР настроены на продолжение своей политики «опоры на собственные силы» и мобилизации гуманитарных и военно-экономических ресурсов для сохранения суверенитета своей страны.

\section{Список источников}

1. Лобов, Р.Н. Социально-экономическое развитие КНДР в условиях санкций // Проблемы национальной стратегии. - 2020. - № 6. - С. 46-59.

2. Михеев, В. В. Болевые точки Пекина 2 (взгляд из середины 2020 г.) / В. В. Михеев, С. А. Луконин // Мировая экономика и международные отношения. 2021. - Т. 65, № 1. - C. 70-81.

3. Самсонова, В. Г. О VIII съезде Трудовой партии Кореи / В. Г. Самсонова, А. Л. Поленова, М. В. Калмыкова // Проблемы Дальнего Востока. - 2021. - № 1. C. $170-175$.

4. Сообщение о 5-м пленуме ЦК ТПК 7-го созыва (2). - URL: http://korealife. do.am/publ/15-1-0-910 (дата обращения: 06.12.2021).

5. Центральное телеграфное агентство Кореи (ЦТАК). - 2020. - 1 февраля.

6. Центральное телеграфное агентство Кореи (ЦТАК). - 2020. - 3 марта.

7. Центральное телеграфное агентство Кореи (ЦТАК). $-2020 .-3$ апреля.

8. East Asian Strategic Review 2020. - Tokyo : The National Institute for Defense Studies, 2020. $-236 \mathrm{p}$.

9. Korean Central News Agency of DPRK (KCNA). - 2020. - 13 April.

10.Korean Central News Agency of DPRK (KCNA). - 2020. - 3 July.

11.Korean Central News Agency of DPRK (KCNA). - 2020. - 10 July.

12. Korean Central News Agency of DPRK (KCNA). - 2020. - 20 August.

13.Korean Central News Agency of DPRK (KCNA). - 2020. - 10 October.

14.Kim Hyung-Jin, N. Korea waging propaganda-heavy labor campaign // The Japan Times. - 2020. - November 16. - P. 5.

15. North Korea's Kim orders tightening of virus steps // The Japan Times. - 2020. November 18. - P. 6.

\section{Информация об авторе}

Лариса Вячеславовна Забровская - ведущий научный сотрудник отдела международных отношений и региональной безопасности Института истории, археологии и этнографии ДВО РАН, доктор исторических наук. 


\section{References}

1. Lobov R. N. Sotsial'no-ekonomicheskoe razvitie KNDR v usloviyakh sanktsii [Socio-economic development of the DPRK under sanctions]. Problemy natsional'noi strategii, 2020, no. 6, pp. 46-59.

2. Mikheev V. V., Lukonin S. A. Bolevye tochki Pekina 2 (vzglyad iz serediny 2020 g.) [Painful points of Beijing 2 (view from the middle of 2020)]. Mirovaya ekonomika i mezhdunarodnye otnosheniya, 2021, vol. 65, no. 1, pp. 70-81.

3. Samsonova V. G., Polenova A. L., Kalmykova M. V. O VIII s"ezde Trudovoi partii Korei [About the VIII Congress of the Labor Party of Korea]. Problemy Dal'nego Vostoka, 2021, no. 1, pp. 170-175.

4. Announcement of the 5th plenum of the Central Committee of the WPK of the 7th convocation (2). Available at: http://korealife.do.am/publ/15-1-0-910 (accessed 06 December 2021).

5. The Central Telegraph Agency of Korea (CTAC), 2020, February 1.

6. The Central Telegraph Agency of Korea (CTAC), 2020, March 3.

7. The Central Telegraph Agency of Korea (CTAC), 2020, March 3.

8. East Asian Strategic Review 2020. Tokyo: The National Institute for Defense Studies, 2020. $236 \mathrm{p}$.

9. Korean Central News Agency of DPRK (KCNA), 2020, 13 April.

10. Korean Central News Agency of DPRK (KCNA), 2020, 3 July.

11. Korean Central News Agency of DPRK (KCNA), 2020, 10 July.

12. Korean Central News Agency of DPRK (KCNA), 2020, 20 August.

13. Korean Central News Agency of DPRK (KCNA), 2020, 10 October.

14. Kim Hyung-Jin N. Korea waging propaganda-heavy labor campaign. The Japan Times, 2020, November 16, P. 5.

15. North Korea's Kim orders tightening of virus steps. The Japan Times, 2020, November 18, pp. 6.

\section{Information about the author}

L. V. Zabrovskaya - Leading Researcher, Department of International Relations and Regional Security, Institute of History, Archeology and Ethnography, Far Eastern Branch of the Russian Academy of Sciences, Doctor of Historical Sciences. 